\title{
Maize (Zea mays) Response to Anthill Soil (Termitaria), Manure and NPK Fertilization Rate under Conventional and Reduced Tillage Cropping Systems
}

\author{
Kafula Chisanga ${ }^{1,2, *}$, Ernest Mbega ${ }^{1}$ and Patrick Alois Ndakidemi ${ }^{1,2}$ \\ 1 Department of Sustainable Agriculture, The Nelson Mandela African Institution of Science and Technology, \\ P.O. Box 447, Arusha 23311, Tanzania; ernest.mbega@nm-aist.ac.tz (E.M.); \\ patrick.ndakidemi@nm-aist.ac.tz (P.A.N.) \\ 2 Centre for Research, Agriculture Advancement, Teaching Excellence and Sustainability (CREATES) in Food \\ and Nutrition Security, The Nelson Mandela African Institution of Science and Technology, P.O. Box 447, \\ Arusha 23311, Tanzania \\ * Correspondence: chisangak@nm-aist.ac.tz
}

Received: 19 November 2019; Accepted: 13 January 2020; Published: 27 January 2020

check for updates

\begin{abstract}
Soil fertility management has been described by many scholars as fundamental and a major hindrance to food production amongst smallholder farmers in the developing world. To counteract this challenge, some farmers have been reported to use anthill soil as analternative fertilizer to improve soil fertility for supporting crop growth. Against this background, a study was undertaken with the aim of ascertaining the effect of anthill soil application alone, cattle manure, and/or their combination with commercially available NPK fertilizer on the growth and yield parameters of three maize varieties under field conditions involving conventional (CONV) and conservation agriculture (CA) tillage systems. Results revealed that anthill soil alone ( $5000 \mathrm{~kg} / \mathrm{ha}$ ) or in combination with either manure $(10,000 \mathrm{~kg} / \mathrm{ha})$ or half rate of commercially available fertilizer (NPKS: $10 \% \mathrm{~N}, 20 \% \mathrm{P}_{2} \mathrm{O}_{5}, 10 \% \mathrm{~K}_{2} \mathrm{O}, 6 \%$ $\mathrm{S}$ at $100 \mathrm{~kg} / \mathrm{ha}$ ) competed favourably in terms of response to growth parameters. Furthermore, $\mathrm{pH}$ and $P$ levels changed significantly $(p<0.05)$ at harvest. We conclude that resource-constrained smallholder farmers in less developed countries utilizing anthill soil for fertility improvement purposes should judiciously apply it in CA planting basin structures compared with conventional methods, which appeared to be less effective and leads to sub-optimal yields.
\end{abstract}

Keywords: agronomic practices; crop yield; food security; soil health; sustainable agriculture

\section{Introduction}

Soils are the basis from which food consumed by the people is produced; thus, they are subject to a myriad of disturbances and stresses from the application of agricultural management practices [1]. Therefore, the management of soil in a sustainable manner is crucial forthemaintenance of adequate production of highly nutritious food and for enhancing future food production and, at the same instance, preserving natural resources and the environment. Considering that around 33 percent of global soil and 40 percent of Africa's soils are already degraded, the Food and Agriculture Organization (FAO) emphasized the need to focus on restoring degraded soils, includingthemaintenance of health [2].

Furthermore, degraded soils are often found in regions where people are distressed by poverty and malnutrition. Restoring and maintaining soil health play an important role to help meet the food demands of growing populations in parts of the world where it is most needed. In recent times, modern agriculture has progressively dependedmoreon inputs of mineral and chemical fertilizers to meet 
plant nutrient requirements [1,2]. This has added to the sharp rise in crop production [3]. However, inefficient management practices have led to large nutrient losses to the environment, thereby raising concerns on the long-term sustainability of the global agriculture sector [2]. Additionally, the cost of the inorganic fertilizers have also hampered some smallholder farmers in the remote areas of the developing world from accessing the input due to their social-economic status amongst other variables. In agreement withthis, Thierfelder et al. [4] confirmed that smallholder farmers normally have no capacity to purchase reasonable quantities of inorganic fertilizers and, therefore, rely more on other available resources.

Availability and use of organic fertilizers such as anthill soil and cattle manure are also increasing significantly due to the increase in cattle populations [1] and easy access to anthills in areas where this resource is abundant. Besides macro and micronutrients, manure makes available organic matter to agricultural soils-a key indicator of soil health. However, inappropriate manure management and unwarranted use can also have injurious effects on the environment, adding to the contamination of water and soil resources and increased greenhouse gas (GHG) emissions [5,6]. Efficient nutrient management plans and strategies are warranted in order to maximize crop productivity while minimizing the potential environmental impact due to the high amount of nutrients being applied today.

In the southern part of Zambia, termite mounds, otherwise known as anthills, are quite abundant and some smallholder farmers in rural areas take advantage of their availability to use part of the soil as an alternative fertilizer. This is done to enhance the organic content of the poor sandy soils which are extremely depleted and has culminatedinto a situation where benefits of commercially available NPKS compound and urea fertilizers (NPKS: $10 \% \mathrm{~N}, 20 \% \mathrm{P}_{2} \mathrm{O}_{5}, 10 \% \mathrm{~K}_{2} \mathrm{O}, 6 \% \mathrm{~S}$ and urea: $46 \% \mathrm{~N}$, $0 \% \mathrm{P}_{2} \mathrm{O}_{5}, 0 \% \mathrm{~K}_{2} \mathrm{O}, 0 \% \mathrm{~S}$ ) are not being accrued, attributing to declined nutrient use efficiency $[7,8]$. Moreover, theuse of anthill soil by smallholder farmers stems from the fact that the cost of commercially available fertilizer is sometimes beyond their reach.Therefore, they look for ways of maintaining the soil condition using organic resources available at their disposal and hence the use of thisresource as part of integrated soil fertility management (ISFM) strategy at the farm scale. From the perspective of soil science, thefertility of the anthills is attributed to termites. They process considerable quantities of materials in their anthill building activities, which has a telling effect on soil properties compared with those of adjacent soils. Scholars have reported soil physical and chemical characteristics changes by termites attributed to their bioturbation activities, with top segments of the anthills reported to have elevated levels of macro- and micronutrients. For instance, it was reported that anthills of African and South American regions built by grass-feeding termites exhibited higher levels of phosphorous in the inner sections compared with the surrounding soils [9]. Bruno et al. [10] also concluded that anthills have low $\mathrm{Zn}$ but higher concentrations of $\mathrm{Na}$ and $\mathrm{Cu}$. Because of thisenrichment in the anthill material, the resource has been used as fertilizer in African crop production where soils have low fertility [11]. However, there are limited studies that have focused on the effects of anthill soil utilization in crop production [12]. Additionally, Mukherjee and Lal [13] also claimed that there is nearly no data currently available on the effects of tillage on organic soil, particularly under smallholder farming systems.

Based on the foregoing, the aim of this work is therefore to evaluate the effect of anthill soil application on the growth and to the yield parameters of three maize varieties (SC 403; PAN 413, and ZMS528) under field conditions involving conventional and conservation agriculture tillage systems. Conventional agriculture is a system of land preparation that involves use of moldboard plough and harrowing while conservation agriculture (CA) is defined based on three principles which must be applied simultaneously, (i) minimum soil disturbance, (ii) permanent soil cover with previous year's crop residues, and (iii) diversification of crop genus in association and/or in sequence [14]. CA is considered to remove the unsustainable elements of conventional agriculture that includes soil tilling, removal of organic material, and monoculture, and encompasses all other principles of sound crop management. The minimum tillage of the land in CA is either by boring the land that leads to making planting basin structures or ripping, using an ox-drawn ripper. In our study under $\mathrm{CA}$, the basin tillage system was adopted. Furthermore, we aspired to generate information that would be instrumental 
in ISFM options for the resource-constrained smallholder farmers cultivating in sandy inherent soils and facing challenges of environmental stresses of low rainfall in southern Africa. Moreover, the present study also evaluated the soil residual effects of treatments on $\mathrm{pH}, \mathrm{P}, \mathrm{Ca}, \mathrm{Mg}, \mathrm{Zn}, \mathrm{Cu}$, and $\mathrm{Fe}$ concentration at the end of harvesting.

\section{Materials and Methods}

\subsection{Study Area}

Choma and Pemba, the study districts are found at latitude $16^{\circ} 50^{\prime} \mathrm{S}$, longitude $27^{\circ} 10^{\prime} \mathrm{E}$ and $16^{\circ} 30^{\prime}$ $\mathrm{S}, 27^{\circ} 28^{\prime} \mathrm{E}$, respectively. Just like in many areas of Zambia, Choma district has a typical climate of southern Zambia with temperatures ranging between $14^{\circ} \mathrm{C}$ in October and $28^{\circ} \mathrm{C}$ in December. Annual rains normally begin in October and go on up to early April. The highest peak for rainfall is observed in January and stops in April. The district records annual rainfall of $830 \mathrm{~mm}$, and a considerable amount of $369 \mathrm{~mm}$ is recorded around January and February. Variations in rainfall distribution are sometimes observed in each season and, as such, haveaninfluence on the yields of crops obtained in the district. The climate of Pemba is generally warm and the average yearly temperature is normally $19.5^{\circ} \mathrm{C}$ with a mean annual rainfall of $848 \mathrm{~mm}$. Summers have high rainfall received during the period. The month of July is the driest and no amount of rainfall is recorded at the time. The month of December records the highest rainfall amounts with a mean of $219 \mathrm{~mm}$. The month of November generally is warmer than any other month. Temperatures normally revolve around $23.1^{\circ} \mathrm{C}$, whilst July is the coldest month $\left(14.0^{\circ} \mathrm{C}\right)$.

\subsection{Experimental Design}

The field experiments were set up in a split plot randomized block design with three replications. The design was generated using the computer software, GEN STAT, 15th edition (www.genstat.co.uk, VSN International). Conventional (CONV) and conservation agriculture (CA) (planting basins) tillage systems were designated as the main treatments. Composition of the sub plots treatments included anthill soil (5000 kg/ha); NPKS compound and urea CO(NH $\left.)_{2}\right)_{2}$ fertilizer full rate (NPKS: $10 \% \mathrm{~N}, 20 \%$ $\mathrm{P}_{2} \mathrm{O}_{5}, 10 \% \mathrm{~K}_{2} \mathrm{O}, 6 \% \mathrm{~S}$ and urea: $46 \% \mathrm{~N}, 0 \% \mathrm{P}_{2} \mathrm{O}_{5}, 0 \% \mathrm{~K}_{2} \mathrm{O}, 0 \% \mathrm{~S}$ at $200 \mathrm{~kg} / \mathrm{ha}$ ); fertilizer half rate (NPKS: $10 \% \mathrm{~N}, 20 \% \mathrm{P}_{2} \mathrm{O}_{5}, 10 \% \mathrm{~K}_{2} \mathrm{O}, 6 \% \mathrm{~S}$ and urea: $46 \% \mathrm{~N}, 0 \% \mathrm{P}_{2} \mathrm{O}_{5}, 0 \% \mathrm{~K}_{2} \mathrm{O}, 0 \% \mathrm{~S}$ at $100 \mathrm{~kg} / \mathrm{ha}$ ) + anthill soil top (5000 kg/ha); fertilizer half rate (NPKS: $10 \% \mathrm{~N}, 20 \% \mathrm{P}_{2} \mathrm{O}_{5}, 10 \% \mathrm{~K}_{2} \mathrm{O}, 6 \% \mathrm{~S}$ and urea: $46 \% \mathrm{~N}, 0 \%$ $\mathrm{P}_{2} \mathrm{O}_{5}, 0 \% \mathrm{~K}_{2} \mathrm{O}, 0 \% \mathrm{~S}$ at $\left.100 \mathrm{~kg} / \mathrm{ha}\right)+$ anthill soil base (5000 kg/ha); urea fertilizer $\left(46 \% \mathrm{~N}, 0 \% \mathrm{P}_{2} \mathrm{O}_{5}, 0 \%\right.$ $\mathrm{K}_{2} \mathrm{O}, 0 \%$ Sat $\left.200 \mathrm{~kg} / \mathrm{ha}\right)+$ anthill soil top (5000 kg/ha); and cattle manure $(10,000 \mathrm{~kg} / \mathrm{ha})+$ anthill soil top $(5000 \mathrm{~kg} / \mathrm{ha})$. The subplot treatments were selected based on data obtained from pot experiment (data not shown). A footpath of $2 \mathrm{~m}$ separated the blocks and the main plots were $90 \times 13.5 \mathrm{~m}$ and $1 \mathrm{~m}$ apart. The size ofthesub-plots was $5 \mathrm{~m}$ long $\times 4.5 \mathrm{~m}$ wide. Spacing between rows was $0.9 \mathrm{~m}$ while planting between stations was $0.3 \mathrm{~m}$ apart with one seed per station. The plant population density for the maize test crop was pegged at 37,037 plants per ha. Three maize varieties were tested in the experiment and included SeedCo 403, PANNAR 413, and ZamSeed 528-all early maturing, with 110-130 days to physiological maturity.

\subsection{Baseline Soil Quality}

Prior to setting up of the field experiments, anthill and control soil samples were collected at the depth of $0-20 \mathrm{~cm}$ from three different points-top, base and $10 \mathrm{~m}$ away from the centre of the anthill-in triplicate form using a soil auger. The collected samples were mixed to form one composite sample of close to one $\mathrm{kg}$ of soil which was later packed in a plastic bag measuring $0.28 \mathrm{~m}$ long $\times 0.16$ $\mathrm{m}$ wide, labeled and taken to the laboratory for analysis. Before analysis was undertaken, samples were shortly stored in a cold room, air-dried, and passed through a $2 \mathrm{~mm}$ sieve. The samples were tested for macro- and micronutrients that included soil $\mathrm{pH}$, nitrogen, phosphorous, potassium, calcium, magnesium, organic carbon, zinc, iron, and copper. In addition, cattle manure samples used as part of 
the treatments in the study were also collected from the heap beside the kraal after scooping using a spade and later packed and taken for analysis.

\subsection{Laboratory Analysis}

All laboratory measurements were determined in three replicates. The soil $\mathrm{pH}$ in water was measured using a $\mathrm{pH}$ meter (LASEC, ACCSEN) in asoil:water ratio of 1:2.5 [15]. Available $\mathrm{P}$ was extracted following the Bray-1 procedure for non-calcareous by shaking $1 \mathrm{~g}$ of air-dried soil in $10 \mathrm{mLof} 0.025 \mathrm{M} \mathrm{HCl}$ and $0.03 \mathrm{M} \mathrm{NH}_{4} \mathrm{~F}$ for $5 \mathrm{~min}$. Available $\mathrm{P}$ was determined on the filtrate by the molybdate-blue method using ascorbic acid as a reductant. Color development was measured using a UV-vis spectrophotometer at $884 \mathrm{~nm}$ wavelength [16]. Organic carbon was determined, followingthesulfochromic oxidation titration method [17]. Total $\mathrm{N}$ was determined by the tecatorstandard Kjeldahl method, which involved a two-step process. Firstly, the sample in a ratio of $1 \mathrm{~g}$ of Kjeldahl catalyst mixture to $2 \mathrm{~mL}$ of $98 \%$ sulfuric acid underwent sulfuric acid digestion that converted ON compounds to $\mathrm{NH}_{4}{ }^{+}$. Secondly, the converted $\mathrm{NH}_{4}{ }^{+}$, along with any $\mathrm{NH}_{4}{ }^{+}$that was originally present, was further converted to $\mathrm{NH}_{3}$ in an alkali distillation process. The $\mathrm{NH}_{3}$ liberated in this process was then quantified to determine the total $\mathrm{N}$ in the original digest. A separately determined value for $\mathrm{NH}_{3}$ and $\mathrm{NH}_{4}{ }^{+}$was then subtracted from the value obtained by the Kjeldahl method, and the difference was the mineralizable or potentially plant-available ON [18]. The cation exchange capacity (CEC) was extracted with a $1 \mathrm{MNH}_{4} \mathrm{OAc}$ solution at the soil $\mathrm{pH}$ of 7.00. The soil-solution slurry was shaken for $2 \mathrm{~h}$, and the solution was separated from the solid by centrifugation. The addition of $\mathrm{NH}_{4}{ }^{+}$in excess to the soil displaced the rapid exchangeable alkali and alkaline cations from the exchange sites of the soil particles. The $\mathrm{NH}_{4}$ exchanged soil was subjected to standard Kjeldahl distillation procedure. The exchangeable bases $(\mathrm{Ca}, \mathrm{Mg}, \mathrm{Na}$, and $\mathrm{K})$ were extracted following a similar procedure. The concentrations of $\mathrm{Na}, \mathrm{K}, \mathrm{Ca}$ and $\mathrm{Mg}$ were subsequently analysed by atomic absorption spectroscopy (AAS-Version UNICAM 919) flame spectrophotometer [19]. Available metallic micronutrients that included $\mathrm{Cu}, \mathrm{Zn}$ and Fe were extracted using the flame atomic absorption spectrometry [20].

Finally, the mineral part of the soil was separated into various size fractions, and the proportions of these fractions were determined by the hydrometer method. The determination comprised all material that included gravel and coarser material but the procedure itself was applied to the fine earth $(<2 \mathrm{~mm})$ only. The pre-treatment of the sample was aimed at the complete dispersion of the primary particles. Cementing materials, i.e, organic matter and calcium carbonate, were removed. After this pre-treatment, the sample was shaken with a dispersing agent and sand was separated from clay and silt with a $63-\mu \mathrm{m}$ sieve [21].

\subsection{Data Collection}

Harvesting of the field experiments was done when the crop reached physiological maturity. Crops were cut close to the ground level using a machete. Sub-samples totaling 74 were randomly picked from a net plot area of $5 \mathrm{~m}$ long $\times 4 \mathrm{~m}$ wide, which was assigned for collection of data. Weighing of 10 sub-sample cobs and 4 stover biomass was later done in order to determine the field weight of the plot. These were afterwards sundried to $12 \%$ moisture content for maize. About thirty percent $(30 \%)$ of maize biomass was left on the ground in the trial field annually. However, foraconventional tillage system, the crop residues were regularly incorporated under the soil [22]. Rainfall gauges were installed at each trial site and data were collected regularly whenever it rained. The collected data were further used to plot graphics to check the performance of the rain during the cropping season. 


\subsection{Data Analysis}

All the data collected in the field experiment were subjected to three-way analysis of variance (ANOVA) with Statistica version 11 (2011) and the Origin Pro 9.0 software, version 90E 2013 programme after application of Shapiro-Wilks $W$ statistical normality tests. Means were compared using Tukey's honestly significant test (HST) at a 95\% confidence interval [23]. Where necessary, Excel version 2010 was employed for plotting graphs and other exclusive computations. The study adopted the linear statistical model for split-plot design [22] as specified below:

$$
\begin{gathered}
\mathrm{Y}_{\mathrm{ijk}}=\mu+\tau_{\mathrm{i}}+\beta_{\mathrm{j}}+(\tau \beta)_{\mathrm{ij}}+\gamma_{\mathrm{k}}+(\tau \gamma)_{\mathrm{ik}}+(\beta \gamma)_{\mathrm{jk}}+(\tau \beta \gamma)_{\mathrm{ijk}}+\varepsilon_{\mathrm{ijk}} \\
\mathrm{i}=1,2, \ldots, \mathrm{rj}=1,2, \ldots, \mathrm{ak}=1,2, \ldots, \mathrm{b}
\end{gathered}
$$

where $\tau_{\mathrm{i}}, \beta_{\mathrm{j}}$ and $(\tau \beta)_{\mathrm{ij}}$ catalog the whole plot and $\gamma_{\mathrm{k}},(\tau \gamma)_{\mathrm{ik}},(\beta \gamma)_{\mathrm{jk}}$ and $(\tau \beta \gamma)_{\mathrm{ijk}}$ catalog the split-plot. Here $\tau_{i}, \beta_{j}$ and $\gamma_{k}$ are block effect, factor A effect and factor B effect, correspondingly.

\section{Results and Discussion}

\subsection{Baseline Data on Soil, Anthill Soil and Manure}

Tables 1-3 presents baseline data on control soil, anthill soil, and manure characteristics used in the field experiments. Results reveal that most macro and micro nutrients were adequate except for phosphorous, organic carbon and $\mathrm{pH}$ in soils used in the experimentation, which were below the critical levels. With regard to texture class, the physical characteristics of the investigated soils were classified into five groups: clay, clay loam, sand, sand clay loam and sandy loam. Wolińska et al. [3] reported that the texture of the soil is crucial as it influences carbon storage and nutrient supply for the soil microorganisms. Therefore the particle size distribution of soil essentially influences the activity of the microbial communities. In this study, we found that the anthill soil had higher content of clay in comparison with the control soil, which exhibited sandy characteristics. As for cattle manure, major macro nutrients were sufficient to support growth except in the Choma study area where Ca levels were below the acceptable limits. 
Table 1. Chemical characteristics of the anthill and control soil used in the experiment.

\begin{tabular}{|c|c|c|c|c|c|c|c|c|c|c|c|c|}
\hline SCA & Area & $\mathrm{pH}$ & $N(g / k g)$ & $\mathrm{P}(\mathrm{mg} / \mathrm{kg})$ & $\mathrm{K}$ & $\mathrm{Ca}(\mathrm{cmol} / \mathrm{kg})$ & $\mathrm{Mg}$ & O.C\% & $\mathrm{Zn}$ & $\mathrm{Cu}(\mathrm{mg} / \mathrm{kg})$ & $\mathrm{Fe}$ & CEC Meq $\%$ \\
\hline CS & PM & $4.3 \pm 0.40$ & $0.6 \pm 0.10$ & $1 \pm 0.10$ & $0.53 \pm 0.10$ & $4.29 \pm 0.40$ & $0.27 \pm 0.03$ & $1.01 \pm 0.10$ & $0.20 \pm 0.02$ & $0.03 \pm 0.0$ & $30.2 \pm 3.02$ & $10.7 \pm 1.10$ \\
\hline AHST & PM & $6.3 \pm 0.60$ & $0.4 \pm 0.00$ & $5 \pm 0.50$ & $0.62 \pm 0.10$ & $88.12 \pm 8.80$ & $4.57 \pm 0.46$ & $0.69 \pm 0.07$ & $1.10 \pm 0.11$ & $0.22 \pm 0.02$ & $32.0 \pm 3.20$ & $87.5 \pm 8.80$ \\
\hline AHSB & PM & $7.3 \pm 0.70$ & $0.5 \pm 0.10$ & $2 \pm 0.20$ & $3.98 \pm 0.40$ & $35.04 \pm 3.50$ & $4.14 \pm 0.41$ & $1.26 \pm 0.13$ & $1.29 \pm 0.13$ & $0.95 \pm 0.10$ & $10.0 \pm 1.00$ & $67.8 \pm 6.80$ \\
\hline CS & $\mathrm{CH}$ & $7.0 \pm 0.70$ & $0.6 \pm 0.10$ & $3 \pm 0.30$ & $0.10 \pm 0.00$ & $0.94 \pm 0.10$ & $0.04 \pm 0.00$ & $1.36 \pm 0.14$ & $0.01 \pm 0.00$ & $0.01 \pm 0.0$ & $40.1 \pm 4.01$ & $2.4 \pm 0.24$ \\
\hline AHST & $\mathrm{CH}$ & $6.5 \pm 0.70$ & $0.6 \pm 0.10$ & $1 \pm 0.10$ & $0.96 \pm 0.10$ & $7.12 \pm 0.70$ & $0.42 \pm 0.04$ & $1.10 \pm 0.11$ & $0.60 \pm 0.06$ & $0.31 \pm 0.03$ & $30.5 \pm 3.10$ & $14.7 \pm 1.50$ \\
\hline AHSB & $\mathrm{CH}$ & $7.5 \pm 0.80$ & $0.8 \pm 0.10$ & $6 \pm 0.60$ & $0.50 \pm 0.10$ & $4.12 \pm 0.40$ & $0.28 \pm 0.03$ & $1.42 \pm 0.14$ & $2.19 \pm 0.22$ & $1.07 \pm 0.11$ & $31.4 \pm 3.14$ & $10.1 \pm 1.01$ \\
\hline \multicolumn{2}{|c|}{ Soil Critical Values } & 4.5 & 0.1 & 15 & 0.2 & 5 & 2 & 1.5 & 0.6 & 0.2 & 10 & 6 \\
\hline
\end{tabular}

NB:SCA = soil collection area; $\mathrm{CS}=$ control soil; AHST = anthill soil top; AHSB = anthill soil base; PM = Pemba and CH=Choma study sites; $\pm=$ Standard deviation $(\mathrm{SD})$. Values were generated from 18 samples collected in triplicate form from experimental sites. 
Table 2. Physical characteristics of the anthill and control soil used in the experiment.

\begin{tabular}{|c|c|c|c|c|c|}
\hline Area & SCA & $\begin{array}{c}\text { Clay (mm) } \\
<0.002\end{array}$ & $\begin{array}{l}\text { Silt (mm) } \\
0.002-0.05\end{array}$ & $\begin{array}{c}\text { Sand }(\mathrm{mm}) \\
0.05-2.0\end{array}$ & $\begin{array}{c}\text { Texture } \\
\text { Class }\end{array}$ \\
\hline \multirow{6}{*}{$\mathrm{PM}$} & Top Anthill & 40.8 & 16.28 & 42.96 & $\mathrm{C}$ \\
\hline & Base Anthill & 40.8 & 14.28 & 44.96 & $\mathrm{C}$ \\
\hline & $10 \mathrm{~m}$ from Anthill & 17.8 & 7.28 & 74.96 & SL \\
\hline & Top Anthill & 87.2 & 0.4 & 12.4 & $\mathrm{C}$ \\
\hline & Base Anthill & 23.9 & 7.7 & 68.4 & SCL \\
\hline & $10 \mathrm{~m}$ from Anthill & 0.3 & 2.4 & 97.3 & $\mathrm{~S}$ \\
\hline \multirow[t]{6}{*}{$\mathrm{CH}$} & Top Anthill & 80.0 & 5.0 & 15.0 & $\mathrm{C}$ \\
\hline & Base Anthill & 39.7 & 17.9 & 42.4 & CL \\
\hline & $10 \mathrm{~m}$ from Anthill & 0.3 & 8.5 & 91.2 & $\mathrm{~S}$ \\
\hline & Top Anthill & 30.2 & 1.4 & 68.4 & SCL \\
\hline & Base Anthill & 21.7 & 7.9 & 70.4 & SCL \\
\hline & $10 \mathrm{~m}$ from Anthill & 0.4 & 7.6 & 92 & S \\
\hline
\end{tabular}

NB: $\mathrm{C}=$ clay; $\mathrm{CL}=$ clay loam; $\mathrm{S}=$ sand; $\mathrm{SCL}=$ sand clay loam; $\mathrm{SL}=$ sand loam; $\mathrm{SCA}$ = soil collection area; $\mathrm{PM}=$ Pemba and $\mathrm{CH}=$ Choma study sites.

Table 3. Chemical characteristics of the manure used in the experiment.

\begin{tabular}{ccccccccc}
\hline Area & $\mathbf{N}(\mathbf{g} / \mathbf{k g})$ & $\mathbf{P}(\mathbf{m g} / \mathbf{k g})$ & $\mathbf{K}$ & $\mathbf{C a}(\mathbf{c m o l} / \mathbf{k g})$ & $\mathbf{M g}$ & $\mathbf{Z n}$ & $\mathbf{C u ~ ( m g / k g )}$ & $\mathbf{F e}$ \\
\hline $\mathrm{PM}$ & 6.1 & 620 & 30.64 & 2.08 & 2.17 & $<0.01$ & $<0.01$ & 0.72 \\
$\mathrm{CH}$ & 3.7 & 150 & 27.05 & 0.20 & 0.65 & $<0.01$ & 0.40 & 0.26 \\
\hline $\begin{array}{c}\text { Soil critical } \\
\text { levels }\end{array}$ & 0.1 & 15 & 0.2 & 5 & 2 & 0.6 & 0.2 & 10 \\
\hline
\end{tabular}

NB: PM = Pemba and $\mathrm{CH}=$ Choma study sites.

\subsection{Rainfall Performance during Experimental Period}

The rainfall characteristics for both Choma and Pemba districts at the time of the study period are depicted in Figure 1A,B. Total rainfall received and number of rain days in the first and second year of test crop growth (2018 and 2019) reflected 854.6 and $788.6 \mathrm{~mm}$, respectively, while total number of rain days in which it rained were 77 and 52, respectively. Nearly all the rainfall peaks for both districts occurred in the month of February, which is very critical as this is the time when the maize crop requires abundant water for grain filling purposes. In the second year 2018/19 season, the two study areas received less than normal rainfall due to the El Nino effects that were affecting the southern African region at the time of the experiment. This resulted in extended dry conditions of more than four weeks that affected crop development. The total seasonal rainfall for the two districts, Choma and Pemba trial sites, were 272.3 and $402.3 \mathrm{~mm}$, respectively. This was far too below the normal rains expected in the districts pegged at $800 \mathrm{~mm}$ by the Zambia Meteorology Department in a season. 


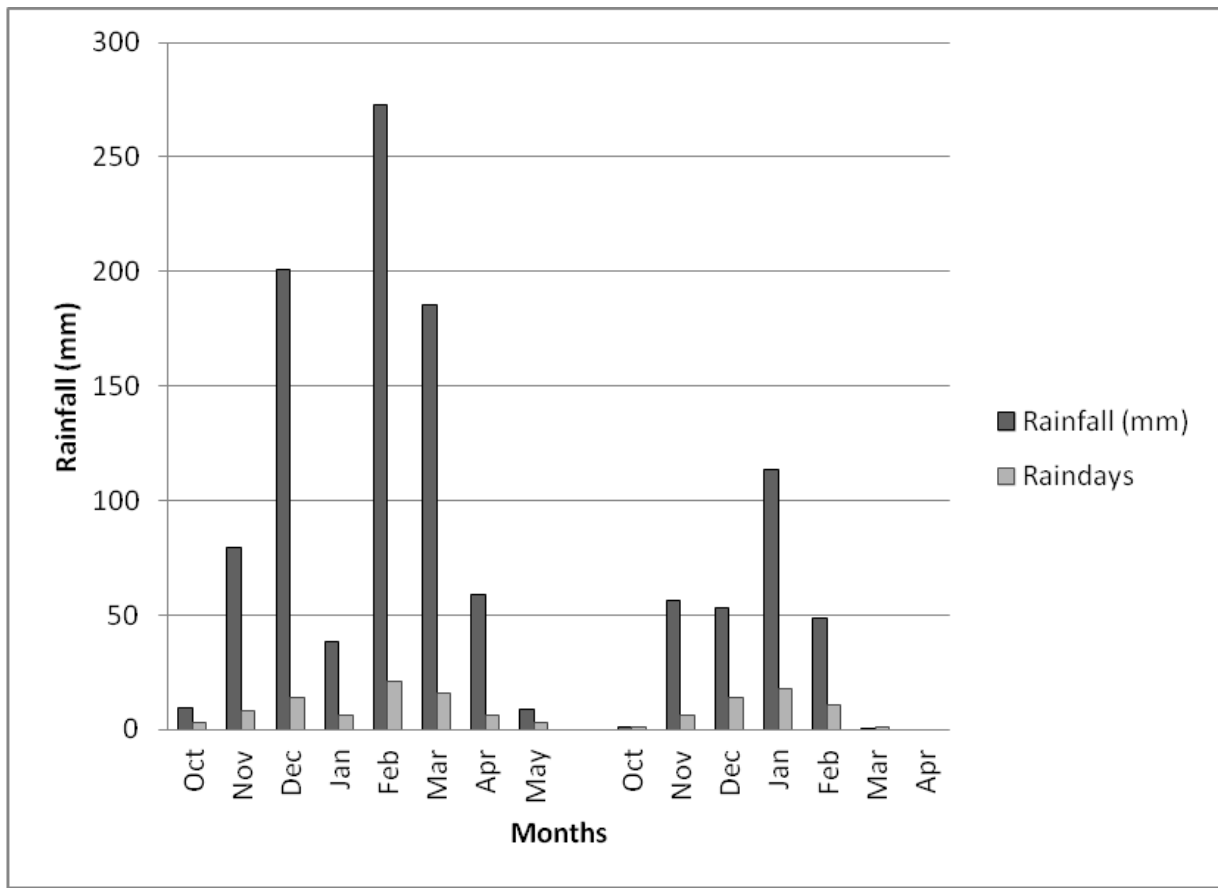

(A)

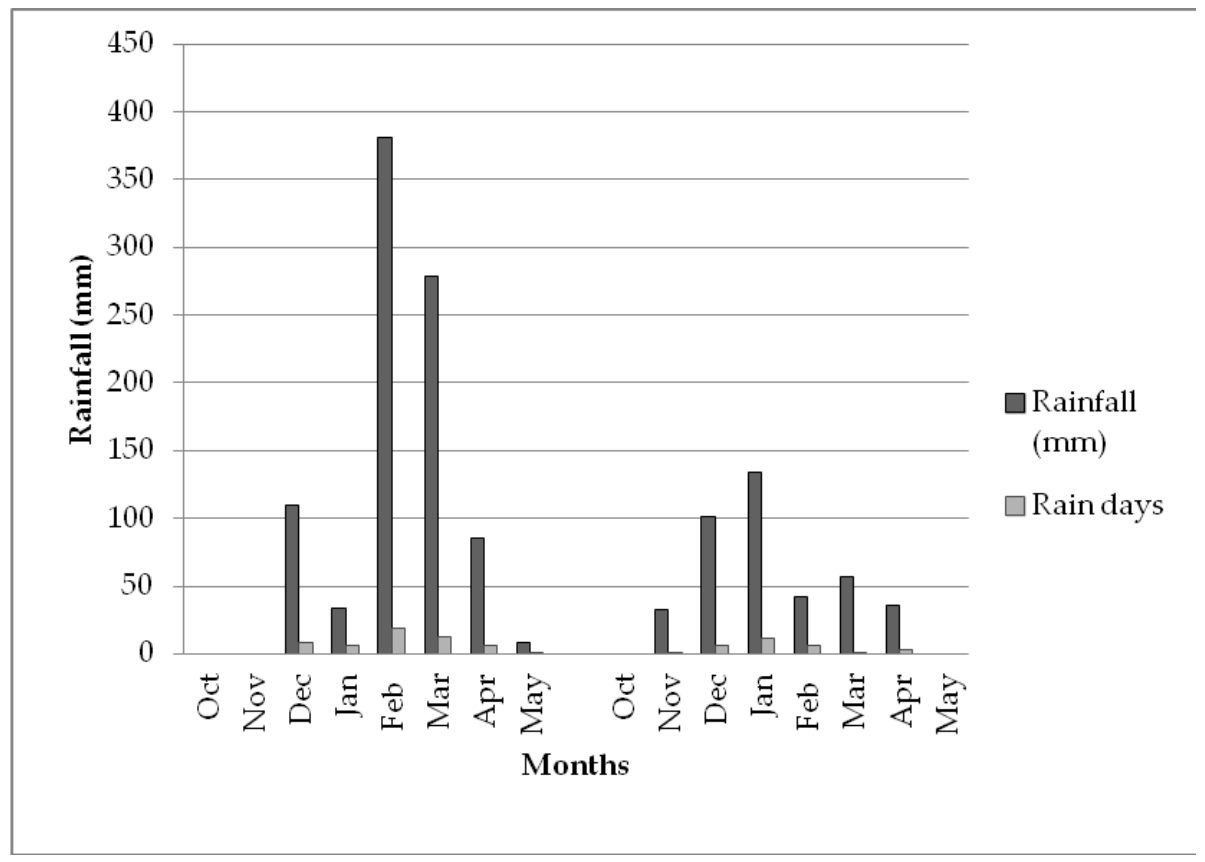

(B)

Figure 1. (A) Comparison of rainfall performance in the Choma study site for 2018 (left graph) and 2019 (right graph)cropping seasons. (B) Comparison of rainfall performance in the Pemba study site for 2018 (left graph) and 2019 (right graph) cropping seasons.

\subsection{Treatment Effects on Growth Parameters}

Tables 4 and 5 shows influence of the treatments on yield and yield components of the tested maize varieties in the Pemba and Choma districts under two tillage systems. Generally, conservation tillage system treatments performed better than convention plots (Figures 2 and 3) for the measured parameters that included, grain, stover and core yields. The underlying reason for this departure 
or differences in yield parameters (grain, stover and core) observed is attributable to the ability of the conservation plots (planting basins structures) to hold water as compared with the conventional practice [22]. The basin tillage capability of holding moisture is due to the limited drainage mechanisms around the structure because of residues presence on the soil which makes it possible for water availability needed for the translocation of the mineral nutrients to the crop [22-24]. In conventional methods however, the probability of the nutrients being washed away is much higher, which is normally a function of slope and soil factors [4]. Idowu et al. [24] indicated that CA normally shields the soil from nutrient erosion through various means such as residues, enhanced moisture retention capacity, and carbon sequestration, including a decrease in the sun rays that impact on temperature of the soil. Nyamangara et al. [25] confirmed that under planting basins similar to what was employed in our work, effects of the treatments are more evident in the early stages of CA due to water collection and soil amendments concentration or a combination.

Almost similar to these findings, [26-29] in their studies on CA practices in southern Africa found that CA treatments performed better than the conventional tillage systems, where $80 \%$ of the generated data indicated gains of CA above conventional tillage systems. CA tillage systems tried in this study appeared to have dealt with the challenges in short to medium-term regarding maize productivity. Other authors [30-33] stressed that the weather conditions during crop growth and soil characteristics of sites have an influence on sustainable crop yields under CA tillage systems.

Additionally, during the growing period, most of the sites did not receive ample rains to warrantanefficient growth of the crop. In both studied sites, the rains received were below normal except for Choma in 2018. Pemba and Choma received 788.6 and $854.6 \mathrm{~mm}$ in the 2018 season while the 2019 season was a challenge as intermittent rains were the order of the day. The prolonged dry spells that went on for more than 4 weeks had a huge impact on the growth of the crop. Additionally, timeliness of the agronomic practices carried out by the experimental host farmers during the growing period of the crop also had a hand in the achieved results. Earlier results from studies on CA in southern Africa have indicated that soil water is fundamental for the responses of CA tillage systems [34-37]. The total rainfall received inthePemba study site was $402.3 \mathrm{~mm}$ while Choma recorded $272 \mathrm{~mm}$. These study areas fall in agro-ecological region II, where maximum rainfall is $800 \mathrm{~mm}$ and categorized as Cwa by the Köppen-Geiger climate classification system [38]. Cwa encounters ten times as much rain received in the wettest month of summer period asthedriest month of winter.

Grain yields for Pemba and Choma in 2018 across the study sites were significantly different $(2017 / 2018, p<0.05)$ and all the treatments performed below the full rate fertilizer (NPK: 10\% N, $20 \% \mathrm{P}_{2} \mathrm{O}_{5}, 10 \% \mathrm{~K}_{2} \mathrm{O}, 6 \% \mathrm{~S}$ and urea: $46 \% \mathrm{~N}, 0 \% \mathrm{P}_{2} \mathrm{O}_{5}, 0 \% \mathrm{~K}_{2} \mathrm{O}, 0 \% \mathrm{~S}$ ) application treatment which was used as a benchmark. However, in the second year of the study, (2019), the combination of half rate fertilizer (NPK: $10 \% \mathrm{~N}, 20 \% \mathrm{P}_{2} \mathrm{O}_{5}, 10 \% \mathrm{~K}_{2} \mathrm{O}, 6 \% \mathrm{~S}$ and urea: $46 \% \mathrm{~N}, 0 \% \mathrm{P}_{2} \mathrm{O}_{5}, 0 \% \mathrm{~K}_{2} \mathrm{O}, 0 \% \mathrm{~S}$ at $100 \mathrm{~kg} / \mathrm{ha})$ + anthill soil base $(5000 \mathrm{~kg} / \mathrm{ha})$ treatment competed favourably with the set inorganic fertilizer recommendations for the studied sites. This could have been attributed to improved release of the nutrients by the anthill soil resulting from enhanced soil infiltration [9]. Additionally, the poor rainfall received at the time of the experiment also impacted heavily on the grain yields achieved in this study. In addition, anthill soil is known to be less effective during the dry conditions as the resource has a high sucking characteristic which also causes it to be hard, thereby hampering the bioavailability of nutrients to the crop [9,33]. Kaew Achan et al. [39] also substantiated that the anthill soil requires more water, attributed to the high suction properties compared with adjacent soil. This fundamentally affected the yield gains observed in this study as an outcome of erratic rains recorded during the cropping season. 
Table 4. Crop response to anthill soil amendment under conventional (CONV) and conservation agriculture (CA) tillage systems; the Pemba Site.

\begin{tabular}{|c|c|c|c|c|c|c|}
\hline \multirow[b]{2}{*}{ Tillage practice } & \multicolumn{2}{|c|}{$\begin{array}{l}\text { Stover Yield }(\mathrm{kg} / \mathrm{ha}) \\
2018 \text { and } 2019\end{array}$} & \multicolumn{2}{|c|}{$\begin{array}{l}\text { Grain Yield (kg/ha) } \\
2018 \text { and } 2019\end{array}$} & \multicolumn{2}{|c|}{$\begin{array}{l}\text { Core Yield }(\mathrm{kg} / \mathrm{ha}) \\
2018 \text { and } 2019\end{array}$} \\
\hline & & & & & & \\
\hline CA & $231.44 \pm 10.4 a$ & $199.31 \pm 12.0 \mathrm{a}$ & $1376.63 \pm 44.3 a$ & $716.39 \pm 43.1 \mathrm{a}$ & $359.18 \pm 13.9 a$ & $112.07 \pm 6.0 \mathrm{a}$ \\
\hline $\mathrm{CON}$ & $230.86 \pm 9.2 \mathrm{a}$ & $194.51 \pm 11.0 \mathrm{a}$ & $1292.44 \pm 36.8 b$ & $759.40 \pm 51.4 a$ & $330.71 \pm 9.3 b$ & $91.63 \pm 5.6 b$ \\
\hline \multicolumn{7}{|l|}{ Fertilizer level } \\
\hline $1=\mathrm{AHT}$ & $180.86 \pm 15.3 a$ & $182.72 \pm 18.3 a$ & $1228.40 \pm 75.6 a$ & $602.47 \pm 59.3 a$ & $345.06 \pm 15.5 a$ & $86.83 \pm 10.3 a b$ \\
\hline $2=\mathrm{FRF}$ & $208.33 \pm 12.4 a b$ & $211.11 \pm 23.6 a$ & $1242.59 \pm 74.2 a$ & $818.72 \pm 70.7 a$ & $327.78 \pm 23.04 a$ & $119.34 \pm 11.6 b$ \\
\hline $3=\mathrm{FRF}+\mathrm{AHT}$ & $267.97 \pm 18.7 \mathrm{c}$ & $186.00 \pm 23.1 a$ & $1505.01 \pm 71.8 b$ & $786.21 \pm 77.3 a$ & $394.34 \pm 23.6 b$ & $111.11 \pm 10.9 \mathrm{ab}$ \\
\hline $4=\mathrm{HRF}+\mathrm{AHB}$ & $249.07 \pm 15.3 b c$ & $214.81 \pm 18.7 a$ & $1279.17 \pm 59.9 a$ & $854.73 \pm 111.1 \mathrm{a}$ & $332.41 \pm 17.3 a$ & $115.22 \pm 10.3 b$ \\
\hline $5=$ Urea + AHT & $230.56 \pm 14.9 a b c$ & $178.60 \pm 17.1 a$ & $1262.50 \pm 58.6 a$ & $775.10 \pm 68.1 \mathrm{a}$ & $326.85 \pm 17.9 a$ & $100.82 \pm 8.1 \mathrm{ab}$ \\
\hline $6=\mathrm{M}+\mathrm{AHT}$ & $235.19 \pm 16.6 a b c$ & $208.23 \pm 19.0 \mathrm{a}$ & $1444.44 \pm 59.7 \mathrm{ab}$ & $590.12 \pm 83.9 a$ & $337.5 \pm 18.70 a$ & $77.78 \pm 7.5 \mathrm{a}$ \\
\hline \multicolumn{7}{|l|}{ Maize varieties } \\
\hline $\mathrm{V}_{1}$ & $200.82 \pm 10.8 \mathrm{a}$ & $150.62 \pm 11.3 a$ & $1251.58 \pm 54.6 \mathrm{a}$ & $611.00 \pm 39.8 b$ & $359.18 \pm 13.9 \mathrm{a}$ & $90.95 \pm 7.0 \mathrm{a}$ \\
\hline $\mathrm{V}_{2}$ & $246.84 \pm 11.02 b$ & $223.05 \pm 16.1 b$ & $1373.64 \pm 47.1 \mathrm{a}$ & $862.96 \pm 73.6 \mathrm{ab}$ & $330.71 \pm 9.3 b$ & $113.99 \pm 7.7 a$ \\
\hline $\mathrm{V}_{3}$ & $240.05 \pm 12.4 b$ & $217.08 \pm 11.4 b$ & $1359.03 \pm 47.8 \mathrm{a}$ & $739.71 \pm 48.5 \mathrm{a}$ & $345.06 \pm 15.5 a$ & $100.62 \pm 6.8 \mathrm{a}$ \\
\hline $\begin{array}{l}\text { Summary of All Treatment Effects } \\
\text { (F-Statistics) }\end{array}$ & \multicolumn{2}{|c|}{$\begin{array}{l}\text { Stover Yield (kg/ha) } \\
2018 \text { and } 2019\end{array}$} & \multicolumn{2}{|c|}{$\begin{array}{l}\text { Grain Yield (kg/ha) } \\
2018 \text { and } 2019\end{array}$} & \multicolumn{2}{|c|}{$\begin{array}{l}\text { Core Yield }(\mathrm{kg} / \mathrm{ha}) \\
2018 \text { and } 2019\end{array}$} \\
\hline Tillage & 0.882 & 0762 & $0.038^{*}$ & 0.516 & $0.016^{*}$ & $0.014^{*}$ \\
\hline Fertilizer level & $0.002 *$ & 0.624 & $0.007^{*}$ & 0.093 & 0.001 * & 0.024 \\
\hline Maize varieties & $0.001 *$ & $0.000 *$ & 0.142 & 0.010 * & 0.000 * & 0.074 \\
\hline Tillage $\times$ fertilizer & 0.132 & 0.749 & 0.776 & 0.894 & 0.084 & 0.453 \\
\hline Tillage $\times$ maize varieties & $0.006^{*}$ & 0.139 & 0.539 & 0.375 & 0.431 & 0.333 \\
\hline Fertilizer level $\times$ maize varieties & 0.487 & 0.838 & $0.021 *$ & 0.432 & 0.314 & 0.636 \\
\hline Tillage $\times$ fertilizer $\times$ maize varieties & 0.412 & 0.553 & 0.368 & 0.915 & 0.171 & 0.982 \\
\hline
\end{tabular}

${ }^{*}$ Significant at $p \leq 0.05$ level; ns $=$ not significant. Means in the same column followed by the same letter denote no significance at 0.05 probability level based on Tukey's honest significance test. AHT = anthill soil top $(5000 \mathrm{~kg} / \mathrm{ha}) ; \mathrm{FRF}=$ full rate fertilizer $(200 \mathrm{~kg} / \mathrm{ha}) ; \mathrm{HRF}+\mathrm{AHT}=$ half rate fertilizer $(100 \mathrm{~kg} / \mathrm{ha})+$ anthill soil top $(5000 \mathrm{~kg} / \mathrm{ha}) ; \mathrm{HRF}+\mathrm{AHB}=\mathrm{half}$ rate fertilizer $(100 \mathrm{~kg} / \mathrm{ha})+$ anthill soil base $(5000 \mathrm{~kg} / \mathrm{ha}) ;$ Urea $+\mathrm{AHT}=$ top dressing fertilizer $(200 \mathrm{~kg} / \mathrm{ha})+$ anthill soil top $(5000 \mathrm{~kg} / \mathrm{ha}) ; \mathrm{M}+\mathrm{AHT}=\mathrm{manure}(10,000 \mathrm{~kg} / \mathrm{ha})+$ anthill soil top (5000 kg/ha); $\mathrm{V}_{1}=$ maize variety SC 403; $\mathrm{V}_{2}=$ maize variety PAN 413; $\mathrm{V}_{3}=$ maize variety $Z \mathrm{ZMS} 403 ; \pm$ = standard error of the mean (SEM). 
Table 5. Maize crop response to anthill soil amendment under conventional (CONV) and conservation agriculture (CA) tillage systems;theChoma Site.

\begin{tabular}{|c|c|c|c|c|c|c|}
\hline Variable & \multicolumn{2}{|c|}{$\begin{array}{l}\text { Stover Yield (kg/ha) } \\
2018 \text { and } 2019\end{array}$} & \multicolumn{2}{|c|}{$\begin{array}{l}\text { Grain Yield (kg/ha) } \\
2018 \text { and } 2019\end{array}$} & \multicolumn{2}{|c|}{$\begin{array}{l}\text { Core Yield (kg/ha) } \\
2018 \text { and } 2019\end{array}$} \\
\hline \multicolumn{7}{|l|}{ Tillage practice } \\
\hline CA & $181.73 \pm 10.1 a$ & $107.82 \pm 10.4 a$ & $930.86 \pm 86.9 a$ & $602.54 \pm 38.8 a$ & $152.59 \pm 11.3 a$ & $88.07 \pm 8.4 a$ \\
\hline $\mathrm{CON}$ & $188.98 \pm 10.1 \mathrm{a}$ & $120.44 \pm 11.3 a$ & $771.78 \pm 68.6 a$ & $585.19 \pm 38.7 a$ & $134.96 \pm 8.2 \mathrm{a}$ & $112.34 \pm 8.5 \mathrm{a}$ \\
\hline \multicolumn{7}{|l|}{ Fertilizer level } \\
\hline $1=\mathrm{AHT}$ & $143.43 \pm 14.4 a$ & $60.91 \pm 11.9 \mathrm{a}$ & $578.65 \pm 44.9 a$ & $461.93 \pm 49.9 a$ & $115.15 \pm 5.2 \mathrm{ab}$ & $77.78 \pm 11.9 \mathrm{a}$ \\
\hline $2=\mathrm{FRF}$ & $184.44 \pm 12.3 a$ & $158.44 \pm 19.8 b$ & $506.52 \pm 78.4 a$ & $853.70 \pm 85.9 b$ & $97.04 \pm 5.7 \mathrm{a}$ & $146.09 \pm 20.9 b$ \\
\hline $3=\mathrm{FRF}+\mathrm{AHT}$ & $222.63 \pm 14.8 b$ & $129.22 \pm 19.9 a b$ & $1235.80 \pm 129.9 b$ & $611.32 \pm 63.6 \mathrm{a}$ & $181.48 \pm 17.7 \mathrm{~d}$ & $99.18 \pm 11.9 \mathrm{ab}$ \\
\hline $4=\mathrm{HRF}+\mathrm{AHB}$ & $214.35 \pm 19.6 b$ & $126.75 \pm 17.7 \mathrm{ab}$ & $1014.72 \pm 170.1 \mathrm{ab}$ & $637.65 \pm 56.6 \mathrm{ab}$ & $164.81 \pm 21.7 \mathrm{~cd}$ & $103.29 \pm 12.6 \mathrm{ab}$ \\
\hline $5=$ Urea + AHT & $149.89 \pm 16.6 \mathrm{a}$ & $97.94 \pm 14.9 \mathrm{ab}$ & $832.11 \pm 109.4 \mathrm{ab}$ & $526.95 \pm 47.5 \mathrm{a}$ & $151.63 \pm 16.7 \mathrm{bcd}$ & $90.94 \pm 13.9 \mathrm{ab}$ \\
\hline $6=\mathrm{M}+\mathrm{AHT}$ & $179.89 \pm 10.6 \mathrm{ab}$ & $111.52 \pm 20.9 \mathrm{ab}$ & $676.83 \pm 92.4 a$ & $471.60 \pm 50.1 \mathrm{a}$ & $120.11 \pm 6.6 \mathrm{abc}$ & $83.95 \pm 11.8 \mathrm{a}$ \\
\hline \multicolumn{7}{|l|}{ Maize varieties } \\
\hline $\mathrm{V}_{1}$ & $159.12 \pm 12.1 b$ & $77.36 \pm 10.2 \mathrm{a}$ & $982.22 \pm 118.9 \mathrm{a}$ & $469.96 \pm 39.5 a$ & $155.00 \pm 14.5 a$ & $81.69 \pm 9.6 a$ \\
\hline $\mathrm{V}_{2}$ & $218.90 \pm 12.5 a$ & $124.89 \pm 12.9 b$ & $780.99 \pm 97.4 a$ & $668.72 \pm 49.3 b$ & $147.38 \pm 12.8 a$ & $111.11 \pm 9.8 \mathrm{a}$ \\
\hline $\mathrm{V}_{3}$ & $176.05 \pm 10.0 \mathrm{~b}$ & $140.12 \pm 14.5 \mathrm{~b}$ & $812.09 \pm 75.4 \mathrm{a}$ & $642.90 \pm 46.7 \mathrm{~b}$ & $131.36 \pm 9.7 \mathrm{a}$ & $107.82 \pm 11.5 \mathrm{a}$ \\
\hline $\begin{array}{l}\text { Summary of All Treatment Effects } \\
\text { (F-Statistics) }\end{array}$ & \multicolumn{2}{|c|}{$\begin{array}{l}\text { Stover Yield (kg/ha) } \\
2018 \text { and } 2019\end{array}$} & \multicolumn{2}{|c|}{$\begin{array}{l}\text { Grain Yield }(\mathrm{kg} / \mathrm{ha}) \\
2018 \text { and } 2019\end{array}$} & \multicolumn{2}{|c|}{$\begin{array}{l}\text { Core Yield (kg/ha) } \\
2018 \text { and } 2019\end{array}$} \\
\hline Tillage & 0.700 & 0.383 & 0.076 & 0.727 & 0.256 & 0.053 \\
\hline Fertilizer level & $0.000 *$ & $0.007 *$ & $0.001 *$ & $0.000 *$ & $0.009 *$ & $0.032 *$ \\
\hline Maize varieties & $0.000 *$ & $0.002 *$ & 0.229 & $0.003 *$ & 0.655 & 0.109 \\
\hline Tillage $\times$ fertilizer & 0.961 & 0.871 & 0.836 & 0.426 & 0.851 & 0.564 \\
\hline Tillage $\times$ maize varieties & 0.406 & 0.429 & 0.906 & 0.251 & 0.582 & 0.365 \\
\hline Fertilizer level $\times$ maize varieties & 0.402 & 0.692 & 0.327 & 0.965 & 0.487 & 0.993 \\
\hline Tillage $\times$ fertilizer $\times$ maize varieties & 0.993 & 0.701 & 0.732 & 0.900 & 0.892 & 0.998 \\
\hline
\end{tabular}

${ }^{*}$ Significant at $p \leq 0.05$ level; ns $=$ not significant. Means in the same column followed by the same letter denote no significance at 0.05 probability level based on Tukey's honest significance test. AHT = anthill soil top $(5000 \mathrm{~kg} / \mathrm{ha}) ; \mathrm{FRF}=$ full rate fertilizer $(200 \mathrm{~kg} / \mathrm{ha}) ; \mathrm{HRF}+\mathrm{AHT}=$ half rate fertilizer $(100 \mathrm{~kg} / \mathrm{ha})+$ anthill soil top $(5000 \mathrm{~kg} / \mathrm{ha}) ; \mathrm{HRF}+\mathrm{AHB}=\mathrm{half}$ rate fertilizer $(100 \mathrm{~kg} / \mathrm{ha})+$ anthill soil base $(5000 \mathrm{~kg} / \mathrm{ha}) ;$ Urea $+\mathrm{AHT}=$ top dressing fertilizer $(200 \mathrm{~kg} / \mathrm{ha})+$ anthill soil top $(5000 \mathrm{~kg} / \mathrm{ha}) ; \mathrm{M}+\mathrm{AHT}=\mathrm{manure}(10,000 \mathrm{~kg} / \mathrm{ha})+$ anthill soil top (5000 kg/ha); $\mathrm{V}_{1}=$ maize variety SC 403; $\mathrm{V}_{2}=$ maize variety PAN 413; $\mathrm{V}_{3}=$ maize variety $Z \mathrm{ZMS} 403 ; \pm$ = standard error of the mean (SEM). 

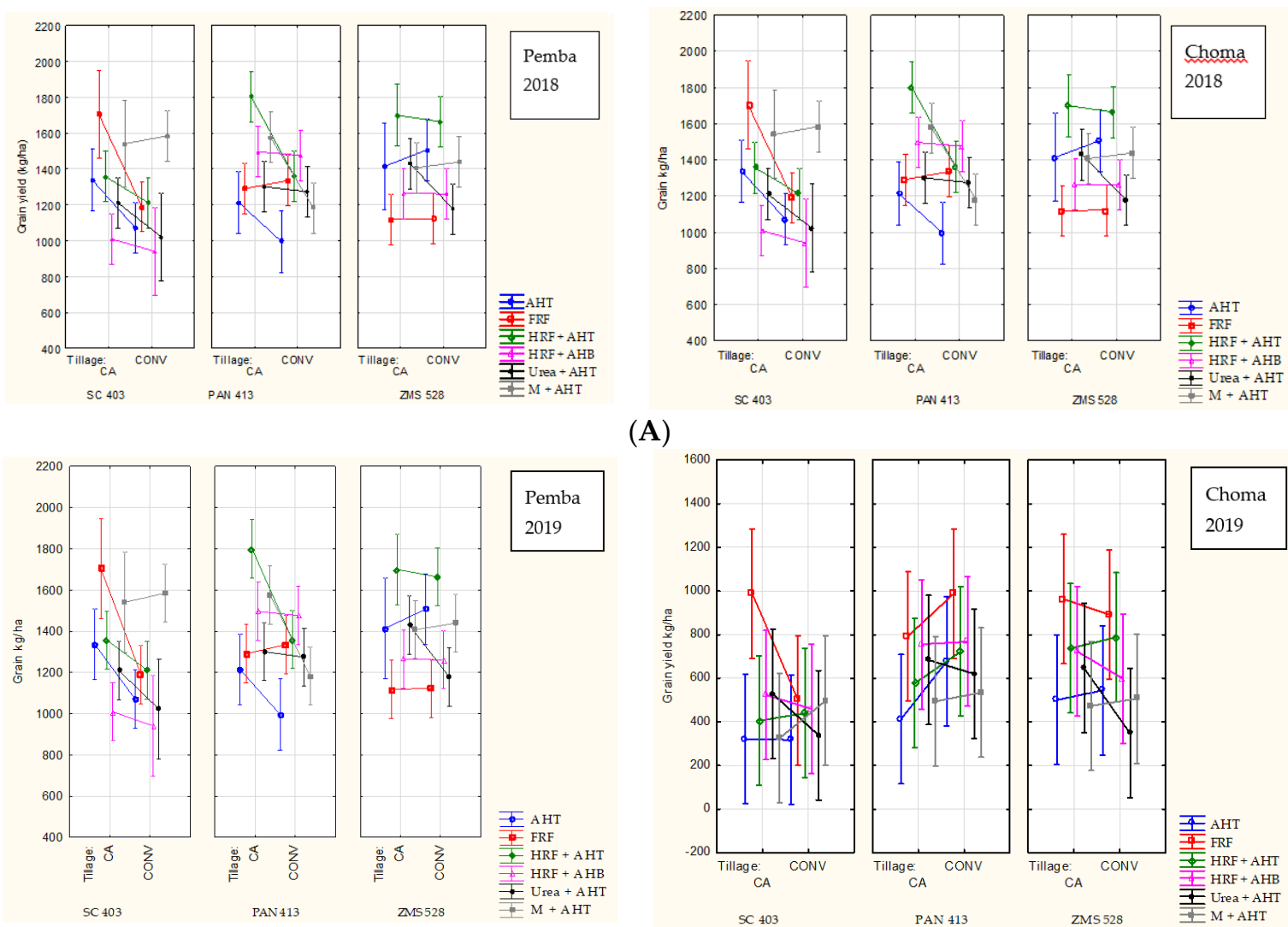

(A)
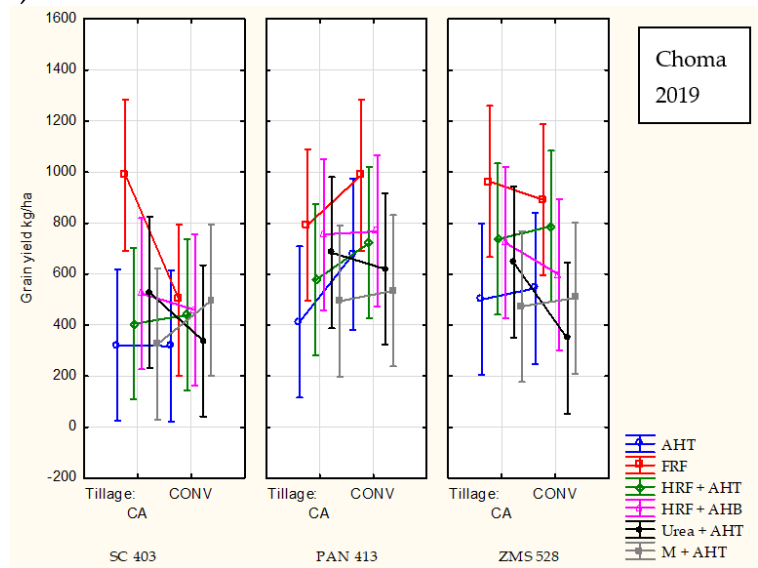

(B)

Figure 2. (A) Main effects plots for the interaction between tillage practices, fertilizer level, and maize varieties across the study sites in 2018. (B) Main effects plots for the interaction between tillage practices, fertilizer level, and maize varieties across the study sites in 2019.

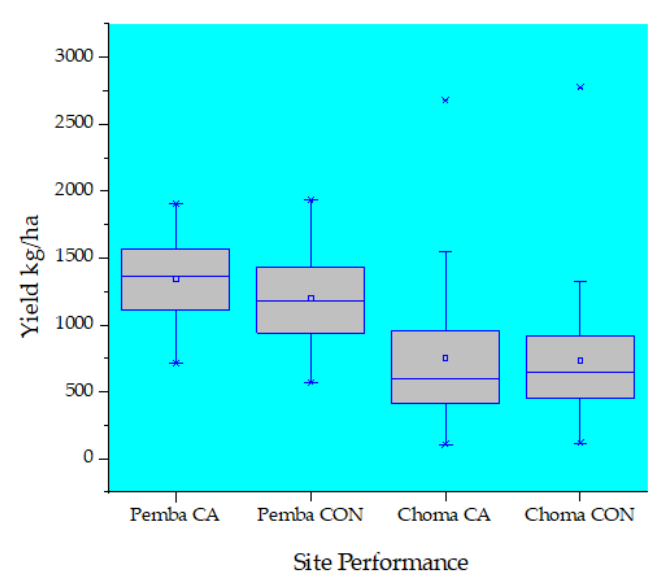

(A)

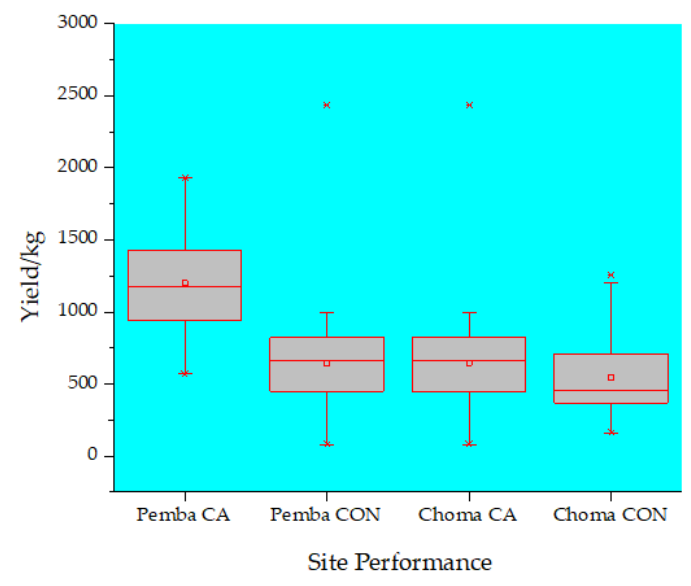

(B)

Figure 3. Box plots showing the mean variations of the tillage system performance in terms of grain yield across the studied sites during 2018 (A) and 2019 seasons (B), respectively. Note CA = conservation agriculture tillage system; $\mathrm{CON}=$ conventional agriculture tillage system.

In both growing seasons, only two factors (fertilizer level and variety) except tillage exhibited a significant effect $(p<0.001)$ on both maize grain yield and the yield components (stover and core) in the studied sites. The interactions, tillage $\times$ fertilizer level and tillage $\times$ variety, were significant only in the first season (2017/2018) and in the Pemba site (Tables 4 and 5). In the subsequent season 
(2018/2019), however, all the other interaction effects were not significant, implying that tillage effects were independent of fertilizer level and variety treatments. Overall, higher responses in terms of stover and core yields were by and large recorded in PAN 413 and ZMS 528 varieties across the studied sites. These varieties showed resilience in the face of low rainfall received during the study period. Thierfelder et al. [40] explained that rainfall regimes that are below $600 \mathrm{~mm}$ in a crop growing season pose a challenge to sustain substantial maize stover production to make available effective soil cover under CA tillage systems. In both our study sites, rainfall was below $600 \mathrm{~mm}$, with Pemba and Choma sites recording $273.3 \mathrm{~mm}$ and $423 \mathrm{~mm}$, respectively.TheChoma site received the lowest precipitation in 46 years according to the available meteorological records. Based on this discourse, we note that smallholder farmers in the studied sites have the potential to reap benefits from growing early maturing maize varieties employed in this study, inspite of environmental stresses such as rainfall variability, that can ensure food security atthehousehold level.

\section{Soil $\mathrm{pH}$, Residual $\mathrm{P}, \mathrm{Ca}, \mathrm{Mg}, \mathrm{Zn}, \mathrm{Cu}$ and Fe at Harvest}

Tables 6 and 7 provides evidence for the effect of anthill soil, manure and NPKS compound and urea fertilizers and/or their combination on selected macro and micro nutrients such as $\mathrm{pH}, \mathrm{P}, \mathrm{Ca}$ $\mathrm{Mg}, \mathrm{Zn}, \mathrm{Cu}$ and $\mathrm{Fe}$ in the current study. Results show that there was a significant variation $(p<0.05)$ in the concentrations of these nutrients at the end of the cropping season. The treatments made available in this study showed that there was a significant $(p<0.05)$ change in soil $\mathrm{pH}, \mathrm{P}, \mathrm{Zn}, \mathrm{Fe}$ and $\mathrm{Cu}$ concentrations in both CONV and CA tillage systems in the Pemba site at the time of harvest (Table 6). Similar increases in soil $\mathrm{pH}$ have also been earlier reported with use of organic amendments in crop production [41,42]. Ca and Mg did not exhibit any significant differences $(p>0.05)$ in the tested tillage systems. This could be attributed to uniform bioavailability of the nutrients at the micro sites. Across the treatments on the other hand, there were significant differences $(p<0.05)$ in $\mathrm{Mg}$ concentrations and they were below the recommended threshold level of $2 \mathrm{cmol} / \mathrm{kg}$. Additionally, more $\mathrm{P}$ was manifested in the half rate fertilizer (NPKS: $10 \% \mathrm{~N}, 20 \% \mathrm{P}_{2} \mathrm{O}_{5}, 10 \% \mathrm{~K}_{2} \mathrm{O}, 6 \% \mathrm{~S}$ and urea $46 \% \mathrm{~N}, 0 \% \mathrm{P}_{2} \mathrm{O}_{5}, 0 \% \mathrm{~K}_{2} \mathrm{O}, 0 \% \mathrm{~S}$ at $\left.100 \mathrm{~kg} / \mathrm{ha}\right)+$ anthill soil top (5000 kg/ha) treatment. All treatments nevertheless, had elevated residual P greater than the optimum of $15 \mathrm{mg} \mathrm{P} / \mathrm{kg}$ set for maize production. Presence of anthill soil may have contributed to the increase in enhanced P availability. During formation of anthills, termites responsible for the activity exude material rich in phosphates catalyzed by phosphatase enzymes [9]. Kwabiah et al. [43] also confirmed that the mineralization of P would occur in the short-range, depending on the enrichment of organic inputs. Residual micro nutrients, $\mathrm{Zn}$, Fe and $\mathrm{Cu}$ showed statistical evidence of significant differences $(p<0.05)$ only in tillage systems and not within the treatments though the values varied. 
Table 6. Effects of anthill soil application, NPK fertilizer or cattle manure and their combination supply on $\mathrm{pH}$, residual P, Ca, Mg, Zn, Fe and Cu in the soil collected near the root zone of the maize test crop at harvest; the Pemba Site.

\begin{tabular}{|c|c|c|c|c|c|c|c|}
\hline Variable & $\mathrm{pH}\left(\mathrm{H}_{2} \mathrm{O}\right)$ & P (mg/g) & $\mathrm{Ca}(\mathrm{cmol} / \mathrm{kg})$ & $\mathrm{Mg}(\mathrm{cmol} / \mathrm{kg})$ & $\mathrm{Zn}(\mathrm{mg} / \mathrm{kg})$ & $\mathrm{Fe}(\mathrm{mg} / \mathrm{kg})$ & $\mathrm{Cu}(\mathrm{mg} / \mathrm{kg})$ \\
\hline \multicolumn{8}{|l|}{ Tillage practice } \\
\hline CA & $6.99 \pm 0.06$ & $17.81 \pm 1.21$ & $5.83 \pm 0.71$ & $0.64 \pm 0.06$ & $0.23 \pm 0.09$ & $118.65 \pm 7.92$ & $0.17 \pm 0.04$ \\
\hline $\mathrm{CON}$ & $7.2 \pm 0.05$ & $22.44 \pm 1.28$ & $5.70 \pm 0.66$ & $0.68 \pm 0.08$ & $3.87 \pm 1.70$ & $230.26 \pm 12.97$ & $6.72 \pm 1.40$ \\
\hline \multicolumn{8}{|l|}{ Fertilizer level } \\
\hline 1 = AHT & $6.93 \pm 0.10$ & $18.22 \pm 1.86$ & $4.79 \pm 0.71$ & $0.59 \pm 0.07$ & $0.01 \pm 0.00$ & $146.17 \pm 23.67$ & $2.06 \pm 1.12$ \\
\hline $2=\mathrm{FRF}$ & $7.06 \pm 0.08$ & $19.83 \pm 1.77$ & $5.37 \pm 1.17$ & $0.66 \pm 0.12$ & $0.37 \pm 0.35$ & $205.74 \pm 19.68$ & $3.54 \pm 1.49$ \\
\hline $3=\mathrm{FRF}+\mathrm{AHT}$ & $7.11 \pm 0.09$ & $22.89 \pm 2.92$ & $8.08 \pm 1.70$ & $0.93 \pm 0.18$ & $3.55 \pm 2.12$ & $159.76 \pm 27.67$ & $5.36 \pm 2.62$ \\
\hline $4=\mathrm{HRF}+\mathrm{AHB}$ & $7.28 \pm 0.04$ & $19.89 \pm 1.78$ & $5.92 \pm 0.89$ & $0.56 \pm 0.07$ & $0.15 \pm 0.14$ & $192.44 \pm 23.19$ & $2.74 \pm 1.19$ \\
\hline $6=\mathrm{M}+\mathrm{AHT}$ & $7.20 \pm 0.09$ & $21.11 \pm 2.79$ & $7.04 \pm 1.39$ & $0.81 \pm 0.14$ & $7.97 \pm 4.55$ & $162.23 \pm 22.14$ & $5.88 \pm 3.01$ \\
\hline \multicolumn{8}{|l|}{ Maize varieties } \\
\hline $\mathrm{V}_{1}$ & $7.12 \pm 0.07$ & $19.02 \pm 1.57$ & $4.99 \pm 0.71$ & $0.60 \pm 0.07$ & $1.91 \pm 1.24$ & $175.25 \pm 16.52$ & $3.34 \pm 1.38$ \\
\hline $\mathrm{V}_{2}$ & $7.11 \pm 0.05$ & $22.69 \pm 1.64$ & $6.28 \pm 0.80$ & $0.68 \pm 0.08$ & $2.47 \pm 1.98$ & $167.98 \pm 14.37$ & $3.28 \pm 1.33$ \\
\hline $\mathrm{V}_{3}$ & $7.07 \pm 0.08$ & $18.67 \pm 1.45$ & $6.03 \pm 0.99$ & $0.70 \pm 0.10$ & $1.77 \pm 1.18$ & $180.13 \pm 17.61$ & $3.73 \pm 1.29$ \\
\hline $\begin{array}{l}\text { Summary of All Treatment Effects } \\
\text { (F-Statistics) }\end{array}$ & $\mathrm{pH}\left(\mathrm{H}_{2} \mathrm{O}\right)$ & P (mg/g) & $\mathrm{Ca}(\mathrm{cmol} / \mathrm{kg})$ & $\mathrm{Mg}(\mathrm{cmol} / \mathrm{kg})$ & $\mathrm{Zn}(\mathrm{mg} / \mathrm{kg})$ & $\mathrm{Fe}(\mathrm{mg} / \mathrm{kg})$ & $\mathrm{Cu}(\mathrm{mg} / \mathrm{kg})$ \\
\hline Fertilizer level & 0.13 & 0.74 & 0.14 & 0.06 & 0.07 & 0.33 & 0.47 \\
\hline Maize varieties & 0.87 & 0.15 & 0.55 & 0.73 & 0.94 & 0.84 & 0.97 \\
\hline Tillage $\times$ fertilizer & 0.32 & 0.17 & 0.45 & 0.74 & 0.08 & 0.37 & 0.43 \\
\hline Tillage $\times$ maize varieties & 0.84 & 0.57 & 0.46 & 0.90 & 0.97 & 0.51 & 0.97 \\
\hline Fertilizer level $\times$ maize varieties & 0.79 & 0.69 & 0.99 & 0.99 & 0.98 & 0.99 & 0.99 \\
\hline Tillage $\times$ fertilizer $\times$ maize varieties & 0.95 & 0.99 & 0.92 & 0.89 & 0.99 & 0.99 & 0.99 \\
\hline
\end{tabular}

* Significant at $p \leq 0.05$ level; ns $=$ not significant. Means in the same column followed by the same letter denote no significance at 0.05 probability level based on Tukey's honest significance test. AHT = anthill soil top $(5000 \mathrm{~kg} / \mathrm{ha}) ; \mathrm{FRF}=$ full rate fertilizer $(200 \mathrm{~kg} / \mathrm{ha}) ; \mathrm{HRF}+\mathrm{AHT}=$ half rate fertilizer $(100 \mathrm{~kg} / \mathrm{ha})+$ anthill soil top $(5000 \mathrm{~kg} / \mathrm{ha}) ; \mathrm{HRF}+\mathrm{AHB}=\mathrm{half}$ rate fertilizer $(100 \mathrm{~kg} / \mathrm{ha})+$ anthill soil base $(5000 \mathrm{~kg} / \mathrm{ha}) ;$ Urea + AHT = top dressing fertilizer $(200 \mathrm{~kg} / \mathrm{ha})+$ anthill soil top $(5000 \mathrm{~kg} / \mathrm{ha}) ; \mathrm{M}+\mathrm{AHT}=\mathrm{manure}(10,000 \mathrm{~kg} / \mathrm{ha})+$ anthill soil top $(5000 \mathrm{~kg} / \mathrm{ha}) ;$

$\mathrm{V}_{1}=$ maize variety SC 403; $\mathrm{V}_{2}=$ maize variety PAN 413; $\mathrm{V}_{3}=$ maize variety ZMS 403; \pm = standard error of the mean (SEM). 
Table 7. Effects of anthill soil application, NPK fertilizer or cattle manure and their combinations supply on $\mathrm{pH}$, residual $\mathrm{P}, \mathrm{Ca}, \mathrm{Mg}$ and Fein the soil collected near the root zone of the maize test crop at harvest; the Choma Site.

\begin{tabular}{|c|c|c|c|c|c|}
\hline Variable & $\mathrm{pH}\left(\mathrm{H}_{2} \mathrm{O}\right)$ & $P(\mathrm{mg} / \mathrm{g})$ & $\mathrm{Ca}(\mathrm{cmol} / \mathrm{kg})$ & $\mathrm{Mg}(\mathrm{cmol} / \mathrm{kg})$ & $\mathrm{Fe}(\mathrm{mg} / \mathrm{kg})$ \\
\hline \multicolumn{6}{|l|}{ Tillage practice } \\
\hline CA & $5.10 \pm 0.04$ & $16.61 \pm 0.74$ & $0.92 \pm 0.03$ & $0.22 \pm 0.01$ & $56.28 \pm 3.10$ \\
\hline $\mathrm{CON}$ & $5.13 \pm 0.04$ & $16.72 \pm 0.96 a$ & $0.89 \pm 0.03$ & $0.22 \pm 0.01$ & $54.85 \pm 3.06$ \\
\hline \multicolumn{6}{|l|}{ Fertilizer level } \\
\hline $1=\mathrm{AHT}$ & $5.14 \pm 0.04$ & $12.78 \pm 0.73$ & $0.94 \pm 0.04$ & $0.23 \pm 0.01$ & $55.07 \pm 5.43$ \\
\hline $2=\mathrm{FRF}$ & $5.11 \pm 0.08$ & $17.89 \pm 1.70$ & $0.84 \pm 0.04$ & $0.21 \pm 0.01$ & $59.99 \pm 5.07$ \\
\hline $3=\mathrm{FRF}+\mathrm{AHT}$ & $5.08 \pm 0.08$ & $17.11 \pm 1.27$ & $0.87 \pm 0.06$ & $0.19 \pm 0.01$ & $57.72 \pm 5.09$ \\
\hline $4=\mathrm{HRF}+\mathrm{AHB}$ & $4.96 \pm 0.06$ & $20.11 \pm 2.05$ & $0.92 \pm 0.04$ & $0.21 \pm 0.01$ & $57.01 \pm 5.16$ \\
\hline $5=$ Urea + AHT & $5.07 \pm 0.05$ & $14.72 \pm 0.96$ & $0.87 \pm 0.05$ & $0.24 \pm 0.02$ & $49.42 \pm 5.50$ \\
\hline $6=\mathrm{M}+\mathrm{AHT}$ & $5.34 \pm 0.26$ & $17.06 \pm 1.29$ & $1.01 \pm 0.08$ & $0.25 \pm 0.01$ & $60.18 \pm 5.92$ \\
\hline \multicolumn{6}{|l|}{ Maize varieties } \\
\hline $\mathrm{V}_{1}$ & $5.13 \pm 0.05$ & $17.56 \pm 1.12$ & $0.93 \pm 0.04$ & $0.22 \pm 0.01$ & $57.27 \pm 3.82$ \\
\hline $\mathrm{V}_{2}$ & $5.15 \pm 0.31$ & $15.19 \pm 0.91$ & $0.86 \pm 0.03$ & $0.21 \pm 0.01$ & $56.46 \pm 3.43$ \\
\hline $\mathrm{V}_{3}$ & $5.07 \pm 0.22$ & $17.08 \pm 1.08$ & $0.93 \pm 0.04$ & $0.23 \pm 0.01$ & $52.97 \pm 4.06$ \\
\hline $\begin{array}{l}\text { Summary of All Treatment Effects } \\
\text { (F-Statistics) }\end{array}$ & $\mathrm{pH}\left(\mathrm{H}_{2} \mathrm{O}\right)$ & $P(\mathrm{mg} / \mathrm{g})$ & $\mathrm{Ca}(\mathrm{cmol} / \mathrm{kg})$ & $\mathrm{Mg}(\mathrm{cmol} / \mathrm{kg})$ & $\mathrm{Fe}(\mathrm{mg} / \mathrm{kg})$ \\
\hline Tillage & 0.58 & 0.85 & 0.43 & 1.00 & 0.78 \\
\hline Fertilizer level & 0.00 * & 0.01 * & 0.30 & 0.08 & 0.83 \\
\hline Maize varieties & 0.37 & 0.24 & 0.32 & 0.31 & 0.76 \\
\hline Tillage $\times$ fertilizer & 0.65 & 0.86 & 0.76 & 0.99 & 0.99 \\
\hline Tillage $\times$ maize varieties & 0.61 & 0.82 & 0.43 & 0.16 & 0.70 \\
\hline Fertilizer level $\times$ maize varieties & 0.83 & 0.99 & 0.88 & 0.93 & 0.98 \\
\hline Tillage $\times$ fertilizer $\times$ maize varieties & 0.18 & 0.16 & 0.44 & 0.71 & 0.99 \\
\hline
\end{tabular}

* Significant at $p \leq 0.05$ level; ns = not significant. Means in the same column followed by the same letter denote no significance at 0.05 probability level based on Tukey's honest significance test. AHT $=$ anthill soil top $(5000 \mathrm{~kg} / \mathrm{ha}) ; \mathrm{FRF}=$ full rate fertilizer $(200 \mathrm{~kg} / \mathrm{ha}) ; \mathrm{HRF}+\mathrm{AHT}=$ half rate fertilizer $(100 \mathrm{~kg} / \mathrm{ha})+$ anthill soil top $(5000 \mathrm{~kg} / \mathrm{ha}) ; \mathrm{HRF}+\mathrm{AHB}=$ half rate fertilizer $(100 \mathrm{~kg} / \mathrm{ha})+$ anthill soil base $(5000 \mathrm{~kg} / \mathrm{ha}) ; \mathrm{Urea}+\mathrm{AHT}=$ top dressing fertilizer $(200 \mathrm{~kg} / \mathrm{ha})+$ anthill soil top $(5000 \mathrm{~kg} / \mathrm{ha}) ; \mathrm{M}+\mathrm{AHT}=\mathrm{manure}(10,000 \mathrm{~kg} / \mathrm{ha})+$ anthill soil top (5000 kg/ha);

$\mathrm{V}_{1}=$ maize variety SC 403; $\mathrm{V}_{2}=$ maize variety PAN 413; $\mathrm{V}_{3}=$ maize variety $\mathrm{ZMS} 403 ; \pm=$ standard error of the mean (SEM). 
As fortheChoma study site, the treatments illustrated no significant variation in soil $\mathrm{pH}, \mathrm{P}, \mathrm{Zn}$, $\mathrm{Fe}$ and $\mathrm{Cu}$ concentrations in both CONV and CA tillage systems (Table 7). However, significant differences $(p<0.05)$ were observed in the variables involving $\mathrm{pH}$ and P. Half rate fertilizer (NPKS: $10 \% \mathrm{~N}, 20 \% \mathrm{P}_{2} \mathrm{O}_{5}, 10 \% \mathrm{~K}_{2} \mathrm{O}, 6 \% \mathrm{~S}$ and urea $46 \% \mathrm{~N}, 0 \% \mathrm{P}_{2} \mathrm{O}_{5}, 0 \% \mathrm{~K}_{2} \mathrm{O}, 0 \% \mathrm{~S}$ at $100 \mathrm{~kg} / \mathrm{ha}$ ) + anthill soil base $(5000 \mathrm{~kg} / \mathrm{ha})$ treatment recorded highest reduction in $\mathrm{pH}$ in comparison to the control soil while residual $\mathrm{P}$ increased. Decreased levels of $\mathrm{pH}$ may have been attributed to the decomposition process of the organic materials [44] in the soil that released organic acids. $\mathrm{Ca}$ and $\mathrm{Mg}$ did not, display any evidence of significant differences $(p>0.05)$ in the tested tillage systems. Nonetheless, there were significant differences within the treatment combinations that raised the residual levels compared with the control soil. This may point to higher content of $\mathrm{Ca}$ and $\mathrm{Mg}$ in anthill soils [45]. Residual micro nutrients were only evident in Fe that displayed no significant differences $(p>0.05)$ between the two tillage systems. However, the levels increased in contrast to the control. The highest value was observed in manure $(10,000 \mathrm{~kg} / \mathrm{ha})+$ anthill top $(5000 \mathrm{~kg} / \mathrm{ha})$ treatment. As for $\mathrm{Cu}$ and $\mathrm{Zn}$, the study did not find any variance after application of treatments in the Choma site. The measured $\mathrm{Cu}$ and $\mathrm{Zn}$ values were below $0.01 \mathrm{mg} / \mathrm{kg}$ measurable concentration levels. This suggested that there could be less ISFM techniques being used by smallholder farmers in the study area for enhancing soil fertility [7]. Manzeke et al. [46] concluded that micronutrient deficiencies are largely high in sub-Saharan Africa (SSA) due to extremely poor soil and less soil fertility management choices at the smallholder farmer level. In support of this assertion, it was also confirmed that deficiencies in nutrients in SSA are common in smallholder farming systems due to poverty and the cultivation of heavy feeder crop genotypes that deplete the already short supply nutrients [47].

\section{Conclusions}

The naturally poor soil fertility condition in the studied areas of the Pemba and Choma districts of southern Zambia offers a menacing challenge to maize production amongst the resource-constrained smallholder farmers coupled with climatic changes and rainfall variablity. Our study has demonstrated that anthill soil top alone $(5000 \mathrm{~kg} / \mathrm{ha})$ or in combination with cattle manure $(10,000 \mathrm{~kg} / \mathrm{ha})$ or half rate of commercially available fertilizer (NPKS: $10 \% \mathrm{~N}, 20 \% \mathrm{P}_{2} \mathrm{O}_{5}, 10 \% \mathrm{~K}_{2} \mathrm{O}, 6 \%$ Sand urea $46 \% \mathrm{~N}$, $0 \% \mathrm{P}_{2} \mathrm{O}_{5}, 0 \% \mathrm{~K}_{2} \mathrm{O}, 0 \% \mathrm{~S}$ at $100 \mathrm{~kg} / \mathrm{ha}$ ) treatments are the best options to embark on for implementing in the smallholder farms. This could essentially enhance accomplishment of maize yields to greater than $1500 \mathrm{~kg} / \mathrm{ha}$ if planting medium, early maturing varieties such as ZMS 528 is adopted by financially-challenged smallholder farmers under the conditions the experiment was established and similar environments. Additionally, the suggested treatment combinations are effectively expected to contribute to improvements in selected soil attributes. The anthill soil is apparently effective in terms of nutrient supply in times of good rain season. The resource principally enhances the performance of the crop, yield and the yield components due to bioavailability of nutrients resulting from moisture presence. In view of the foregoing, we thus suggest that poor resource-constrained smallholder farmers using the anthill soil organic amendment in crop production in African farming systems and other developing countries should prepare and maintain planting basin structures as components of CA tillage systems. This should be implemented much earlier before the on-set of the rain season and incorporate the anthill soil resource in the correct proportions. Mixing with mature cattle manure could also play a pivotal role in attaining optimal yields for ensuring enhanced soil structure, moisture, fertility and consequently food security at the household level. Where irrigation is feasible and a good supply of water guaranteed, benefits of anthill soil to crop production may be immense as the resource requires adequate supply of water to make available the organic matter and other key nutrients. By adopting the aforementioned measures, we aspire to see effective benefits from the anthill soil organic amendment in agriculture production, especially in CA tillage systems at small-scale farm level in southern Africa and similar environments that can compete favourably with commercially available fertilizer. 
Author Contributions: Conceptualization, K.C.; methodology, K.C. and P.A.N.; software, K.C.; validation, P.A.N. and E.M.; formal analysis, K.C.; investigation, K.C.; resources, K.C.; P.A.N. and E.M.; data curation, K.C.; writing-original draft preparation, K.C.; writing-review and editing, P.A.N. and E.M.; visualization, K.C.; supervision, P.A.N. and E.M.; project administration, P.A.N.; funding K.C. and P.A.N. All authors have read and agreed to the published version of the manuscript.

Funding: Funding for this work partly came from the World Bank through the Centre for Research Agriculture Advancement, Teaching Excellence in Sustainability Food and Nutrition Security (CREATES-FNS) of the Nelson Mandela African Institution of Science and Technology, Arusha, Tanzania (Credit No. 5799-TZ) and the Pilot Programme for Climate Resilience (PPCR) of the Ministry of Development and National Planning, Lusaka, Zambia.

Acknowledgments: The authors are grateful to the extension personnel in Choma and Pemba districts in Southern Province, Ministry of Agriculture, Zambia, including farmers for their invaluable support during the period of the study. The research team is also indebted to the Meteorology Department, Southern Province, Zambia for supplying the rainfall satellite imagery maps of the experimental sites.

Conflicts of Interest: The authors declare that there is no conflict of interest.

\section{References}

1. FAO. Nitrogen Inputs to Agriculture Soils from Livestock Manure; FAO: Rome, Italy, 2018.

2. FAO. State of the World's Land and Water Resources for Food and Agriculture (SOLAW)—Managing Systems at Risk; Food and Agriculture Organization: Rome, Italy, 2011.

3. Wolińska, A.; Kuźniar, A.; Zielenkiewicz, U.; Banach, A.; Izak, D.; Stępniewska, Z.; Błaszczyk, M. Metagenomic Analysis of Some Potential Nitrogen-Fixing Bacteria in Arable Soils at Different Formation Processes. Microb. Ecol. 2017, 73, 162-176. [CrossRef] [PubMed]

4. Sutton, M.; Oenema, O.; Erisman, J.W.; Leip, A.; Grinsven, H.; Winiwarter, W. Too much of a good thing. Nature 2011, 472, 159-161. [CrossRef] [PubMed]

5. Thierfelder, C.; Baudron, F.; Setimela, P.; Nyagumbo, I.; Mupangwa, W.; Mhlanga, B.; Lee, N.; Gérard, B. Complementary practices supporting conservation agriculture in southern Africa. A review. Agron. Sustain. Dev. 2018, 38, 16. [CrossRef]

6. Tubiello, F.N.; Salvatore, M.; Rossi, S.; Ferrara, A.; Fitton, N.; Smith, P. The FAOSTAT database of greenhouse gas emissions from agriculture. Environ. Res. Lett. 2013, 8, 015009. [CrossRef]

7. Nezomba, H.; Mtambanengwe, F.; Tittonell, P.; Mapfumo, P. Point of no return? Rehabilitating degraded soils for increased crop productivity on smallholder farms in eastern Zimbabwe. Geoderma 2015, 239, $143-155$. [CrossRef]

8. Mtambanengwe, F.; Mapfumo, P. Combating food insecurity on sandy soils in Zimbabwe: The legume challenge. Symbiosis 2009, 48, 25-36. [CrossRef]

9. López-Hernández, D.; Brossard, M.; Fardeau, J.C.; Lepage, M. Effect of different termite feeding groups on P sorption and P availability in African and South American savannas. Biol. Fertil. Soils 2006, 42, 207-214. [CrossRef]

10. Bruno, G.L.; Johannes, L.; Maike, F. Carbon and nitrogen mineralization in cultivated and natural savanna soils of Northern Tanzania. Biol. Fertil. Soils 2001, 33, 301-309.

11. Siame, A. Termite mound as fertilizer. LEISA 2005, 7, 27.

12. Fageria, N.K.; Baligar, V.C. Properties of Termite Mound Soils and Responses of Rice and Bean to Nitrogen, Phosphorus, and Potassium Fertilization on such Soil. Commun. Soil Sci. Plant Anal. 2005, 35, 2097-2109. [CrossRef]

13. Mukherjee, A.; Lal, R. Tillage effects on quality of organic and mineral soils under on-farm conditions in Ohio. Environ. Earth Sci. 2015, 74, 1815-1822. [CrossRef]

14. FAO. Sourcebook on Climate Smart Agriculture, Forestry and Fisheries'; Food and Agriculture Organization of the United Nations: Rome, Italy, 2013.

15. VanReeuwijk, L.P. Procedures for Soil Analysis, 4th ed.; International Soil Reference and Information Centre (ISRIC): Wageningen, The Netherlands, 1993.

16. Bray, R.H.; Kurtz, L.T. Determination of total, organic, and available forms of phosphorus in soils. Soil Sci. 1945, 59, 39-46. [CrossRef]

17. Walkley, A.; Black, I.A. An examination of the Degtjareff method for determining soil organic matter and a proposed modification of the chromic acid titration method. Soil Sci. 1934, 37, 29-38. [CrossRef] 
18. Page, A.L. Method of Soil Analysis, Part 2, Chemical and Microbiological Properties; Madison: Wisconsin, WI, USA, 1982.

19. VanReeuwijk, L.P. Procedures for Soil Analysis, 6th ed.; International Soil Reference and Information Centre (ISRIC) - World Soil Information: Wageningen, The Netherlands, 2002.

20. Lindsay, W.L.; Norvell, W.A. Development of a DPTA soil test for zinc, iron, manganese and copper. Soil Sci. Soc. Am. J. 1978, 42, 421-428. [CrossRef]

21. AgriLASA. AgriLASA Soil Handbook; AGRILASA: Sasolburg, South Africa, 2004; p. 109.

22. Alam, M.K.; Bell, R.W.; Salahin, N.; Pathan, S.; Mondol, A.T.M.A.I.; Alam, M.J.; Rashid, M.H.; Paul, P.L.C.; Hossain, M.I.; Shil, N.C. Banding of Fertilizer Improves Phosphorus Acquisition and Yield of Zero Tillage Maize by Concentrating Phosphorus in Surface Soil. Sustainability 2018, 10, 3234. [CrossRef]

23. Castro, A.; Batista, N.D.S.; Latawiec, A.E.; Rodrigues, A.; Strassburg, B.; Silva, D.; Araujo, E.; Moraes, L.F.D.; Guerra, J.G.; Galvao, G.; et al. The Effects of Gliricidia-Derived Biochar on Sequential Maize and Bean Farming. Sustainability 2018, 10, 578. [CrossRef]

24. Idowu, J.O.; Sultana, S.; Darapuneni, M.; Beck, L.; Steiner, R. Short-term Conservation Tillage Effects on Corn Silage Yield and Soil Quality in an Irrigated, Arid Agroecosystem. Agronomy 2019, 9, 455. [CrossRef]

25. Nyamangara, J.; Nyengerai, K.; Masvaya, E.N.; Tirivavi, R.; Mashingaidze, N.; Mupangwa, W.; Dimes, J.; Hove, L.; Twomlow, S. Effect of Conservation Agriculture on Maize Yield in the Semi-Arid Areas of Zimbabwe. Exp. Agric. 2013, 50, 159-177. [CrossRef]

26. Mupangwa, W.; Twomlow, S.; Walker, S. Cumulative effects of reduced tillage and mulching on soil properties under semi-arid conditions. J. Arid Environ. 2013, 91, 45-52. [CrossRef]

27. Thierfelder, C.; Wall, P.C. Effects of conservation agriculture on soil quality and productivity in contrasting agro-ecological environments of Zimbabwe. Soil Use Manag. 2012, 28, 209-220. [CrossRef]

28. Mupangwa, W.; Twomlow, S.; Walker, S. Reduced tillage, mulching and rotational effects on maize (Zea mays L.), cowpea (Vigna unguiculata (Walp) L.) and sorghum (Sorghum bicolor L. (Moench)) yields under semi-arid conditions. Field Crops Res. 2012, 132, 139-148. [CrossRef]

29. Ngwira, A.R.; Aune, J.B.; Mkwinda, S. On-farm evaluation of yield and economic benefit of short term maize legume intercropping systems under conservation agriculture in Malawi. Field Crops Res. 2012, 132, $149-157$. [CrossRef]

30. Pittelkow, C.M.; Liang, X.; Linquist, B.A.; Van Groenigen, K.J.; Lee, J.; Lundy, M.E.; Van Gestel, N.; Six, J.; Venterea, R.T.; Van Kessel, C. Productivity limits and potentials of the principles of conservation agriculture. Nature 2015, 517, 365-368. [CrossRef] [PubMed]

31. Wang, X.B.; Cai, D.X.; Hoogmoed, W.B.; Oenema, O.; Perdok, U.D. Potential Effect of Conservation Tillage on Sustainable Land Use: A Review of Global Long-Term Studies. Project supported by the National Natural Science Foundation of China (No. 40571151), the Beijing Key Lab of Resources Environment and GIS at Capital Normal University, and the National High Technology Research and Development Program of China (863 Program) (Nos. 2002AA2Z4311 and 2002AAZ4021). Pedosphere 2006, 16, 587-595.

32. Stevenson, J.R.; Cassman, K.G.; Serraj, R. Evaluating conservation agriculture for small-scale farmers in Sub-Saharan Africa and South Asia. Agric. Ecosys. Environ. 2014, 187, 1-10. [CrossRef]

33. Giller, K.E.; Corbeels, M.; Nyamangara, J.; Triomphe, B.; Affholder, F.; Scopel, E.; Tittonell, P.A. A research agenda to explore the role of conservation agriculture in African smallholder farming systems. Field Crops Res. 2011, 124, 468-472. [CrossRef]

34. Mupangwa, W.; Twomlow, S.; Walker, S. The influence of conservation tillage methods on soil water regimes in semi-arid southern Zimbabwe. Phy. Chem. Earth. 2008, 33, 762-767. [CrossRef]

35. Thierfelder, C.; Wall, P.C. Effects of conservation agriculture techniques on infiltration and soil water content in Zambia and Zimbabwe. Soil Tillage Res. 2009, 105, 217-227. [CrossRef]

36. Mupangwa, W.; Walker, S.; Twomlow, S. Start, end and dry spells of the growing season in semi-arid southern Zimbabwe. J. Arid Environ. 2011, 75, 1097-1104. [CrossRef]

37. Thierfelder, C.; Chisui, J.L.; Gama, M.; Cheesman, S.; Jere, Z.D.; Bunderson, W.T.; Eash, N.S.; Rusinamhodzi, L. Maize-based conservation agriculture systems in Malawi: Long-term trends in productivity. Field Crops Res. 2013, 142, 47-57. [CrossRef]

38. Santos Nouri, A.; Costa, J.P.; Santamouris, M.; Matzarakis, A. Approachesto Outdoor Thermal Comfort Threshholds through Public Space Design: A Review. Atmosphere 2018, 9, 108. [CrossRef] 
39. Kaew Achan, K.P.; Nitichotiskang, A.; Sanguansub, S. Comparative Study of Mechanical Properties of Anthill Soil and Original Soil; Khonkaen University: Khonkaen, Thailand, 2014.

40. Ngwira, A.; Aune, J.B.; Thierfelder, C. On-farm evaluation of the effects of principles and components of conservation agriculture on maize yield and weed biomass in Malawi. Exp. Agric. 2014, 50, 591-610. [CrossRef]

41. Savin, I. The Effect of Organic and Inorganic Amendments on Phosphorous Release and Availability from Two Phosphate Rocks and Triple Super Phosphate in Phosphorous Fixing Soils. Master's Thesis, University of Nairobi, Nairobi, Kenya, 2000.

42. Kpomblekou, A.K.; Tabatabai, M.A. Effect of low-molecular weight organic acids on phosphorous release and phytoavailability of phosphorous in phosphate rocks added to soils. Agric. Ecosyst. Environ. 2003, 100, 275-284. [CrossRef]

43. Kwabiah, A.B.; Palm, C.A.; Stoskopf, N.C.; Voroney, P. Response of soil microbial biomass dynamics to quality of plant materials with emphasis on P availability. Soil Biol. Biochem. 2003, 35, 207-216. [CrossRef]

44. Ndakidemi, P.A. Dry Bean Response to Fertilization Using Minjingu Phosphate Rock and Composted Tughutu (Vernonia subligera O. Hoffn). Am. J. Exp. Agric. 2014, 6, 51-59. [CrossRef]

45. Sarcinelli, T.S.; Schaefer, G.R.; Lynch, L.; Arato, H.D.; Viana, J.H.M.; Filho, M.R.A.; Goncalves, T.T. Chemical, physical and micromorphological properties of termite mounds and adjacent soils along a toposequence in Zona da Mata, Minas Gerais State, Brazil. Catena 2008, 76, 107-113. [CrossRef]

46. Manzeke, M.G.; Mtambanengwe, F.; Watts, M.J.; Hamilton, E.M.; Lark, M.R.; Broadley, M.R.; Mapfumo, P. Fertilizer management and soil type influence grain zinc and iron concentration under contrasting smallholder cropping systems in Zimbabwe. Sci. Rep. 2019, 9, 6445. [CrossRef]

47. Gabriel, S.; Nyamangara, J.; Nyakatawa, E.Z. Nutrient status of sandy soils in smallholder areas of Zimbabwe and the need to develop site-specific fertilizer recommendations for sustainable crop intensification. S. Afr. J. Plant Soil 2018, 36, 149-151. [CrossRef]

(C) 2020 by the authors. Licensee MDPI, Basel, Switzerland. This article is an open access article distributed under the terms and conditions of the Creative Commons Attribution (CC BY) license (http://creativecommons.org/licenses/by/4.0/). 